\title{
NIE PRZYCHODZA \\ UCHODŹCY. AKTUALNE POTRZEBY EDUKACJI POLONISTYCZNEJ (W STRONĘ EDUKACJI NA RZECZ POKOJU)
}

\author{
JOANNA ROSZAK ${ }^{1}$ \\ (Instytut Slawistyki Polskiej Akademii Nauk, Warszawa)
}

Słowa kluczowe: uchodźcy, edukacja globalna, edukacja dla pokoju

Key words: refugees, global education, education for peace

\begin{abstract}
Abstrakt: Joanna Roszak, NIE PRZYCHODZĄ UCHODŹCY. AKTUALNE POTRZEBY EDUKACJI POLONISTYCZNEJ (W STRONE EDUKACJI NA RZECZ POKOJU). „PORÓWNANIA" 20, 2017. T. XX, S. 173-188. ISSN 1733-165X. Autorka artykułu akcentuje potrzebę konfrontowania młodzieży z tematem Innych (etnicznych, narodowościowych, religijnych), co wiąże się ze stosunkowo nową sytuacją społeczną i polityczną, z nasilającymi się ruchami migracyjnymi. Polska szkoła powinna zobaczyć dla siebie istotne zadanie w kontekście światowego nomadyzmu i eskalującego kryzysu humanitarnego. Podczas etapu zbierania materiałów przeprowadzono wywiady skategoryzowane z nauczycielami, bibliotekarzami i uczniami dziesięciu poznańskich szkół. W artykule dokonano analizy i interpretacji zawartości podręczników do nauczania języka polskiego oraz zaproponowano realizację tematów powiązanych z wątkiem uchodźczym. Płynie z niego wniosek, że najważniejszym zadaniem, stojącym przed polską edukacją na wszystkich szczeblach, wydaje się wprowadzenie, nieobecnej dotąd w programie, edukacji na rzecz pokoju.
\end{abstract}

Abstract: Joanna Roszak, THE REFUGEES AREN'T COMING. CURRENT NEEDS IN THE POLISH EDUCATION (TOWARDS EDUCATION FOR PEACE). "PORÓWNANIA" 20, 2017. Vol. XX, P. 173-188. ISSN 1733-165X. The author of the article emphasizes the need to confront the youth with the theme of "the others" (in an ethnic, national and religious sense). It is associated with a relatively new social and political situation: the intensifying migratory movement. Polish schools should see for themselves the important issue in the context of the escalating humanitarian crisis and global nomadism. During the phase of collecting materials for the paper categorized interviews with teachers, librarians and students of ten schools in Poznan were conducted. The author of article analyzes and interprets the content of textbooks used in teaching the Polish language and literature and proposed projects of topics associated with the theme of refugees. The conclusion of the article is that the most important task for the Polish education, at all levels, appears to be the introduction of education for peace.

1 E-mail: joannamroszak@gmail.com 
Przypatrz się teraz sobie: komu się pokłonisz Koтu drzwi otworzysz, a przed kim je zamkniesz?

(Emre 23)

Zawsze na drzwi spogląaj, nie opuszczaj wzroku; Szczęście twe we drzwiach stanie, więc ich pilnuj, nie odchodź!

(Emre 39)

Patrza na nas dzieci. Apel autorów książek dla dzieci w sprawie przyjmowania uchodźców.

\section{Wstęp}

Nauczyciel wprowadza ucznia w bogactwo tradycji własnego narodu, ale także uczy poszanowania kultury innych narodów i grup etnicznych (Kodeks Etyki Nauczycielskiej), „wrażliwości społecznej, myślenia i wyrażania opinii w oparciu o fakty" (por. Materiały Centrum Edukacji Obywatelskiej, Rozmawiajmy o uchodźcach, oraz Chromiec, Morawska). Naucza także odwagi cywilnej w występowaniu przeciwko dyskryminacji i przemocy, wykształca postawy obywatelskie. Potrzeba zatem nauczycieli, którzy potrafią reagować na uczniowskie sądy o Innych², wypowiadane przez młodzież podczas lekcji i poza nią. Jerome Bruner przedostatni rozdział Kultury edukacji zatytułował Wiedzieć jako działać. Nauczycielskie „wiedzieć jak działać” zwykle prowadzi do uczniowskiego „wiedzieć jako działać”, to znaczy do przekuwania wiedzy na konkretne zachowania słowne i pozasłowne.

Mierzenie się podczas lekcji z tematyką uchodźczą wynika najczęściej z indywidualnego przekonania nauczycielki bądź nauczyciela o wadze tego tematu. Iwona Morawska pisała, że zjawisko migracji, obok globalizacji i glokalizacji, narzuca „konieczność rozwiązań, które z jednej strony sprzyjałyby umacnianiu i wzbogacaniu, dowartościowywaniu odrębności kulturowych, z drugiej strony przeciwdziałały segregacji, izolacji kulturowej, zamykaniu się" (Morawska 93). Nasilenie ruchów migracyjnych wymusza potrzebę konfrontowania młodzieży z tematem etnicznych, narodowościowych czy religijnych Innych (Piskorski). Wszelako ponad 65 milionów obywateli świata to dziś uchodźcy - głównie z Syrii, Afganistanu, Iraku, Kosowa, Albanii, Pakistanu i Erytrei. Kwestia uchodźstwa stała się wyzwaniem globalnym na liście Celów Zrównoważonego Rozwoju ONZ do 2030 roku. Kry-

2 Jakkolwiek użyłam kategorii Innego, nadmieniam, że nieobce jest mi poczucie Dereka Attridge'a: "«Inny», trzeba przyznać, jest trochę nadużywanym słowem w obecnym dyskursie uniwersyteckim i może wydawać się zbyt pompatyczną lub nawet nieprecyzyjną kategorią [...]. Ma jednak pewne zalety. Jedną z nich jest sugestia, że mimo iż ten rodzaj spotkania [...] jest powtarzalny i zdarza się każdemu, zawsze jest spotkaniem jednostkowym i spotkaniem z jednostkowością" (Attridge 49). 
zys humanitarny związany z migracjami nasilił się w 2015 roku, a jego medialne nagłośnienia doprowadziły do polaryzacji opinii społecznej (por. Inni to także my), przekazy prasowe coraz częściej podsycają niechęć wobec obcych, nie bazują na rzetelnych danych, ale na atawizmach i strachu (por. Piskorski).

Polska szkoła w kontekście eskalującego kryzysu humanitarnego i światowego nomadyzmu, któremu towarzyszy równie wyjątkowa skala nie tylko znieczulicy, ale i nienawiści, winna więc nadać Inności właściwe znaczenie. Zwłaszcza że Agnieszka Mikulska-Jolles w raporcie z 2016 roku Młodzi Polacy a uchodźcy - co już na ten temat wiemy? zaznaczyła, że grupa w wieku od 18 do 36 lat najbardziej wrogo odnosi się do uchodźców i uchodźczyń (Mikulska-Jolles 23). Równie przygnębiające wnioski płynęły z raportu przygotowanego przez Stowarzyszenie Czulent, dotyczącego tematyki żydowskiej, treści antysemickich i schematów argumentacyjnych w podręcznikach szkolnych - badaniem objętych zostało ponad 170 książek, wiele $\mathrm{z}$ nich niewolnych od nacjonalizmu i antysemityzmu ${ }^{3}$.

Z obserwacji i przeprowadzonych przeze mnie ankiet ${ }^{4}$ wynika jasno, że ten, kto wykazuje niechęć do Żydów i Romów, odczuwa ją także w stosunku do uchodźców, a w szczególności do Arabów i wyznawców islamu. Antysemityzm i postawy antyuchodźcze łączy to, że w definicji zawierają obcość, projekcję (przemieszczona frustracja, reakcje ucieczkowe), nienawiść i wrogość (Makówka-Kwapisiewicz 13).

We wstępie książki Władysława Bartoszewskiego i Marka Edelmana I była dzielnica żydowska w Warszawie czytamy: „Historia, tak jak przysłowiowa fortuna, prawdopodobnie także w następnych stuleciach będzie toczyć się kołem. Nie oznacza to jednak, że nie dane są nam środki wpływania na jej przebieg. Poprzez skuteczną edukację" (Bartoszewski, Edelman 8-9).

W tekście Mój Edelman Bartoszewski przytoczył słowa uczestnika powstania $\mathrm{w}$ getcie warszawskim:

3 Autorki analizy Antysemityzm nie jest pogladem: Alina Cała, Bożena Keff i Anna Lipowska-Teutsch.

4 Narzędzie ankietowe, którym przebadano 30 poznańskich nauczycieli i nauczycielek języka polskiego oraz 10 bibliotek szkolnych i 5 zespołów klasowych, zawierało 20 pytań, dotyczących możliwości angażowania uczniów, propozycji doboru tekstów, mogących budować empatię w stosunku do uchodźczyń i uchodźców, oraz prowadzenia zajęć z elementami edukacji na rzecz pokoju. W kierowanej do nauczycieli i nauczycielek oraz uczniów i uczennic ankiecie uzyskałam odpowiedzi, że zdaniem ankietowanych literatura może kształtować pozytywne postawy i zachowania (por. Bourdieu 572). Wśród omawianych w szkołach tekstów budujących szacunek dla Innego i niechęć do przemocy w zespołach uczniowskich wskazano tytuły: Biblia, O psie, który jeździł koleją (Roman Pisarski), Ten obcy (Irena Jurgielewiczowa), Pinokio (Carlo Collodi), Chłopcy z Placu Broni (Ferenc Molnar), Mała księżniczka (Frances Hodgson Burnett), Maty Ksiażę (Antoine de Saint Exupéry), Dziewczynka spoza szyby (Jadwiga Ruth-Charlewska), Dziewczynka z zapatkami (Hans Christian Andersen), Zabawa w klucz (Ida Fink), Strasznie głośno, niesamowicie blisko (Jonathan Safran Foer), Oskar i Pani Róża (Éric-Emmanuel Schmitt), Kamienie na szaniec (Aleksander Kamiński), Złodziejka książek (Markus Zusak), poezja Tadeusza Różewicza, reportaże - m.in. Anny Wojtachy Kruchy lód i Wojciecha Tochmana Dzisiaj narysujemy śmierć. 
Trzeba dać mieszkanie bitemu. Trzeba go schować w piwnicy. Trzeba się go nie bać. [...] Jeżeli się przyglądasz złu i odwracasz głowę, albo nie pomagasz, kiedy możesz pomóc, to stajesz się współodpowiedzialny. Bo twoje odwrócenie głowy pomaga tym, którzy dopuszczają się zła (Bartoszewski 12).

Nie dość dobrze odrobione przez polską szkołę zadanie związane z historią życia i śmierci Żydów wpływa obecnie na ton rozmowy o uchodźcach lub jej brak. Podczas lekcji języka polskiego, także historii, wiedzy o społeczeństwie, etyki, religii, godziny wychowawczej widać jak na dłoni poglądy uczniów - również te niewolne od uprzedzeń. Pozwalają zdiagnozować, jaki system wartości wyznają uczniowie, zintegrować zespół, reagować na syndromy postaw uprzedzeniowych i konfliktowych, zaangażować się w dawanie wzorów zachowań, a wreszcie propagowanie i rozwijanie takich cnót, jak życzliwość, altruizm i solidarność.

W Zagubionej dziewczynce Eleny Ferrante na neapolitańskiej ulicy, gdzie ostatni raz widziano małą Tinę, która znikła bez śladu, współczujący mieszkańcy dzielnicy zostawiali kartki z kondolencjami, zdjęcia, zabawki i „,[...] nawet zostawiano wiersze przepisane z podręczników" (Ferrante 427). Czym zatem różni się edukacja we Włoszech i w Polsce, skoro w podobnej sytuacji na polskiej ulicy zapewne nie znaleziono by wierszy przepisanych z podręczników do kształcenia polonistycznego. Prócz trenów Jana Kochanowskiego i Władysława Broniewskiego nie znajduję w nich wszelako utworów, które mogłyby sprostać podobnej sytuacji, nie znajduję też wielu takich, które pozwalałyby rozmawiać na temat uchodźców czy wojen toczonych przez nie-Polaków, a wreszcie - były apoteozą raczej pokoju niźli wojny. Tymczasem wiersze pozwalają na konsolidację i zawiązywanie wspólnoty, ukuwanie - by wyrazić się słowami Michała Pawła Markowskiego - życia na miarę literatury (Markowski). Mogą pełnić rolę pocieszycieli lub nauczycieli, bo podczas lekcji języka polskiego młodzież ma nierzadko do czynienia z dwojgiem nauczycieli - tekstem i polonistą. W tym duchu w autobiograficznym tomie Dziewczynka pisała Alona Frankel, autorka książek dla dzieci, która jako kilkulatka przeżyła lwowskie getto:

Cosette z Nędzników, wielkoduszny mały lord, Tomek Sawyer, Kruszynka i Antoś, Emil i wszyscy detektywi, Mowgli i Bagheera - Czarna Pantera, Jan Krzysztof, Dawid Copperfield, d'Artagnan, Dawid z rodziny Thibault i Sergiej z Burzy Ilii Erenburga, Konstanty Lewin i Pierre Biezuchow, błękitnooki książę Myszkin, mały Ernest Nemeczek z Chłopców z Placu Broni i dzielny Oliver Twist.

Dziękuję wam, moi bohaterowie.

Jesteście nauczycielami, których nigdy nie miałam.

Jaka szkoda, że nie miałam nauczyciela (Frankel 12).

Ze wskazanej plejady bohaterek i bohaterów uczeń czy uczennica polskiej szkoły pozna tylko Tomka Sawyera i Nemeczka. W tej samej książce Frankel zapisała 
jeszcze jedno zdanie, warte przywołania w kontekście tematu niniejszego artykułu: "Antysemici, to znaczy przeciwni Żydom, powiedział mój tata. Chcą zabić tych Żydów, których nie zdążyli wymordować Niemcy. [...] Powiedział, że to tylko kwestia wychowania" (Frankel 17).

W procesie wychowania zawsze trzeba mieć na uwadze Innego, tworzenie relacji, reinterpretację stereotypów i pozyskiwanie wiedzy o świecie z kilku źródeł, zapobieganie temu, co nigeryjska pisarka Chimamanda Adichie nazwała „niebezpieczeństwem jednej historii” i niebezpieczeństwem opowiadania historii od „po drugie" (Adichie) - a zatem np. ukazania historii uchodźców i uchodźczyń bez opowieści o wojnach czy katastrofach jako źródle ucieczki. Przeciwdziałanie stereotypom demonstruje także eksperyment przeprowadzony przez Amnesty International na podstawie ustaleń Arthura Arona, według którego zaledwie cztery minuty patrzenia sobie w oczy przez obcych ludzi zbliża ich do siebie. Podobny efekt jak spotkanie z ową „żywą biblioteką" może przynieść spotkanie z tekstem literackim.

\section{Spotkanie}

Podczas zbierania materiałów przeprowadziłam wywiady skategoryzowane z nauczycielami i bibliotekarzami poznańskich szkół. Do katalogu żadnej z objętych badaniem bibliotek szkolnych nie włączono takich książek, jak: Wędrówka Nabu Jarosława Mikołajewskiego, poświęcona uchodźcom z Doniecka Teraz tu jest nasz dom Barbary Gawryluk, Franceski Sanny Podróż, Hebanowe serce Renaty Piątkowskiej. Ewa Nowak oparła fabułę na prawdziwej historii z 2015 roku: los uchodźców ukazała przez pryzmat irackiej rodziny, matki i pięciorga dzieci, jej kota Kunkusha, który rozdzielony z właścicielami, odnalazł ich. Rafał Witek w Chłopcu z Lampedusy ukazał losy Tandżina, uchodźcy-sieroty z Erytrei na wyspę Lempedusa. Także Shaun Tan w książce graficznej Przybysz opowiada historię mężczyzny, opuszczającego dom w poszukiwaniu nowego miejsca dla rodziny.

Wspomniany Mikołajewski napisał na temat uchodźców również reportaż Wielki przyptyw, tom wierszy Żebrak oraz kolędę. Trzykrotnie zatem zmieniał rejestr języka - z dziecięcego na reportażowy i wreszcie poetycki. W tradycji biblijnej zamieszczenie napisu na krzyżu Jezusa w kilku językach interpretuje się jako brak usprawiedliwienia niewiedzy któregokolwiek ze świadków. Podobnie można interpretować gest Mikołajewskiego. W tomie poetyckim zamieścił wiersz wstawienniczy, wprost poświęcony sytuacji uchodźców, a raczej kryzysowi rodzimej polityki migracyjnej i kryzysowi postaw obywatelskich, wiersz-apostrofę, zatytułowany do uchodźców, zaś w reportażu Wielki przyptyw, poświęconym Lampedusie, zobrazował zaś los uchodźców, skupiając się na odmienionym przez nich życiu kilkorga rozmówców, mieszkańców tej małej włoskiej wyspy, której sytuacja staje się parabolą i każe unieważnić zdanie Johna Donne'a: „Nikt nie jest samotną wyspą” (Donne 5). 
Wygnanie stało się tematem eseju Czesława Miłosza, który przypominał, że ziemia jest "ostatecznie ziemią wygnańców Ewy" i kreślił anegdotę o wizycie uchodźcy w biurze podróży: „Uchodźca z rozdzieranej wojną Europy szuka kontynentu i kraju, gdzie można by żyć dostatecznie daleko i bezpiecznie. W zamyśleniu obraca palcem globus i wreszcie pyta: "Czy nie macie czegoś innego?»" (Miłosz 207). Przydatne egzemplifikacje znajdą się w tekstach literackich spoza podręczników i w obrazach filmowych (por. Mościcki oraz Ostatni z Aleppo).

Do większości podręczników drugiego etapu kształcenia włączono opowiadanie Jarosława Iwaszkiewicza Ikar. Interpretując je, można położyć akcent na związek z mitem, realia życia w wojennej Warszawie, motyw książki zbójeckiej albo wreszcie rozważać niedostatek empatii. Żaden z obecnie funkcjonujących na rynku podręczników nie wykorzystuje jednak jako kontekstu wiersza W. H. Audena Musée des Beaux Arts, pozwalającego wrócić do jednego ze źródeł tekstu Skamandryty, do obrazu Bruegla Upadek Ikara. Wiersz pozwala na rozmowy o postawach ludzi wobec cierpienia: racjonalizowaniu go („to nie nasz problem, to daleko, nie jestem w stanie pomóc, cierpią, więc zapewne na to zasłużyli"), co wpisuje się w postawy wobec uchodźców i uchodźczyń:

W sprawach cierpienia nigdy się nie pomylili

Starzy Mistrzowie: jak dobrze rozumieli jego człowiecze

Miejsce w świecie; to, że się zdarza zawsze w tej samej chwili,

Gdy ktoś inny je, wietrzy izbę, albo gdzieś się ospale wlecze;

Że, kiedy grono starców przyklęka ze czcią i nieśmiało,

Czekając cudownych narodzin, muszą pętać się też na uboczu

Dzieci, którym specjalnie na cudzie nie zależało,

Więc gonią się, rumiane, pod lasem na ślizgawce;

Mistrzowie nigdy nie tracili z oczu

Faktu, że najstraszniejsze męczeństwo spełnia się zawsze

Gdzieś w zapuszczonym kącie najdalszego planu,

Gdzie psy są wciąż zajęte psim życiem, a koń oprawcy

Ociera swój niewinny zad o pień platanu.

Taki na przykład Ikar Breughela: ta flegmatyczna swoboda,

Z jaką wszystko odwraca wzrok od tragedii; oracz opodal

Mógł słyszeć plusk i samotny krzyk, ale uznał, że trzeba

Machnąć ręką, że nie był to ważny upadek; słońce

Rzucało normalny blask na białe nogi, niknące

W zieleni wód; a misterny statek, precyzyjnie prujący fale,

Choć widział ten dziw: młodzieńca spadającego z nieba,

Miał swój punkt docelowy i płynął spokojnie dalej.

(Auden 11) 
Na przyległościach mapy Europy, gdzieś w prawym dolnym rogu, jak ginący Ikar na obrazie Starego Mistrza, leży Syria, od siedmiu lat ogarnięta wojną, a w niej wschodnie Aleppo, które w grudniu 2016 roku „utonęło" przy odwróconych oczach wielu mieszkańców świata.

Lustra świata, Świat w stowach i obrazach, Stowa na czasie, Zrozumieć tekst, zrozumieć człowieka to tylko wybrane tytuły programów i podręczników do kształcenia polonistycznego - intytulacja ta po części zawiodła przy konfrontacji z zawartością książek. Z niedostateczną determinacją uczą życia w pokoju, poszanowaniu innych kultur, ponadto: nie zwracają oczu ucznia ku problemom narodów innych niż polski. Wielokrotne, niemal coroczne zmiany w podręcznikach pozwalałyby na wprowadzenie (choćby w częściach testowych, przygotowujących do wypracowania mechanizmów rozwiązywania arkusza egzaminacyjnego) tekstów publicystycznych lub poetyckich, dotyczących aktualnej sytuacji innych krajów Europy, Azji i Afryki, tym samym stworzono by możliwość budzenia empatii. Korzyści mogłoby przynieść włączenie do podręczników zdjęć uciekających przed wojną matek z dziećmi z wystaw World Press Photo (przy ikonologii piety), opowiadań ze zbioru NieObcy. 21 opowieści, żeby się nie bać. Polscy pisarze dla uchodźców, fragmentów reportaży Stefano Libertiego Na południe od Lampedusy, Jonathana Littela Zapisków z Homs, Wolfganga Bauera Przez morze. Z Syryjczykami do Europy, Małgorzaty Szejnert Wyspa klucz (Grecję określa się dziś wszak jako Ellis Island Europy), esejów Zygmunta Baumana Obcy u naszych drzwi czy literatury świadectwa osobistego z czasu wojen, choćby ogłoszonego w 1943 na łamach żydowskiego pisma "The Menorah Journal" eseju Hannah Arendt We refugees (My, uchodźcy), w którym manifestuje się wołanie o podmiotowość nieosiadłych:

Straciliśmy dom, to znaczy całe swojskie codzienne życie. Straciliśmy swój zawód, czyli poczucie, że jesteśmy jakoś potrzebni na świecie. Straciliśmy swój język, czyli możność naturalnego, spontanicznego reagowania [...]. [...] nasi najlepsi przyjaciele zginęli w obozach koncentracyjnych; nasze osobiste życie zostało przecięte (Arendt 300).

[...] kiedyś byliśmy kimś dla kogoś; ludziom na nas zależało; kochali nas przyjaciele [...]. Kiedyś mogliśmy kupować żywność, jeździć metrem - i nikt nam nie wytykał naszej obecności. (Arendt 304).

Nie zapomnę młodego człowieka, który zmuszony do przyjęcia pewnego rodzaju pracy, westchnął: „Pani nie wie, kim ja jestem.... Byłem przecież szefem oddziału u Karstadta (wielki dom towarowy w Berlinie). Lecz zrozumiała jest także rozpacz człowieka w średnim wieku, który szukał ratunku w różnych komitetach i ciągle zbywany niczym, w końcu krzyknął: „Nikt tu nie wie, kto ja jestem”. Skoro nikt nie potraktował go po ludzku, zaczął wysyłać telegramy do wielkich osobistości i swych wpływowych krewnych. Szybko przekonał się, że na tym szalonym świecie łatwiej zostać zaakceptowanym jako „wielki człowiek” niż po prostu jako istota ludzka (Arendt 305). 
Nie wykorzystano też należycie literackich, filmowych i fotograficznych świadectw dzieci i tekstów poświęconych równolatkom odbiorców. Należą do nich m.in. Jesień młodości Miriam Akavii, Strasznie głośno, niesamowicie blisko Jonathana S. Foera, Dziennik Anne Frank (wyjątek stanowi podręcznik Po polsku; z badań przeprowadzonych przeze mnie w 2016 roku w dwóch poznańskich szkołach wynika, że 97\% dzieci nie potrafi dopasować biogramu do nazwisk Janusz Korczak i Anna Frank) oraz fragmenty rodzimych dzienników z Zagłady: dzieci Reni Knoll, Dawidka Rubinowicza albo dorosłej Racheli Auerbach:

Opowiadał mi ktoś w tych dniach, jak szedł za dwiema dziewczątkami i podsłuchał ich rozmowę. Brzmiało to jak bajka. Taki duży, duży, duży ogród, do którego wchodziło się bez opłaty (Wielkie zdziwienie słuchaczki: „To naprawdę nic nie kosztuje?!!!”). Ścieżki i klomby. A co to znaczy „klomby”? Dyskusja ugrzęzła na trudnych objaśnieniach, na glosach słownych do tej legendy przeszłości. Widząc na stole parę gałązek bzu w słoju z wodą, jedna pani prosiła mnie dzisiaj o "pożyczenie" kawałka bzu, by mogła go pokazać swemu dziecku, które jeszcze w swoim życiu bzu nie widziało i pyta: „a co to jest bez?" „Taki kwiat” "A co to jest kwiat” (Auerbach 145-146).

Nicholas Kristof w sierpniu 2016 roku opisał historię wolontariuszki porządkującej podania uchodźcze wpływające do Nowego Jorku w czasie II wojny światowej. Wśród wniosków składanych przez dzieci trafiła ona na pismo od Anne Frank wraz z załączonymi listami jej ojca, Ottona Franka, szukającego w Ameryce, Wielkiej Brytanii i na Kubie pomocy w ucieczce przed nazistami. Żadne podanie nie zostało rozpatrzone pozytywnie (Kristof). Anne Frank zmarła w 1945 roku w wieku 16 lat w obozie koncentracyjnym Bergen-Belsen, niedługo przed oswobodzeniem przez Brytyjczyków. „Niczego się nie uczymy” - brzmi podsumowanie artykułu w „New York Times"; globalna obojętność na los Żydów znajduje dziś odpowiednik w obojętności na los ludzi z miejsc ogarniętych wojnami.

Henryka Kwiatkowska w książce Przeżycie literackie a moralne postawy uczniów zaznaczyła potrzebę wyposażenia ucznia w wartości „poznawczo-prakseologiczne" (Kwiatkowska 5) i kształtowanie przez literaturę, w sposób kompleksowy: "emocjonalny, intelektualny, wolicjonalny" (Kwiatkowska). Trudno nie przyznać słuszności głównej tezie jej opracowania: „Przeżycie jest zatem najwłaściwszą formą poznania wartości dzieła” (Kwiatkowska 19), „ma [...] charakter osobisty, jest przeżyciem, które czerpie siłę wzruszenia z własnego losu odbiorcy, działa urokiem skojarzeń i przypomnień" (Kwiatkowska 32). Powinno się zatem tak dobierać teksty literackie, by wzmagać postawę opiekuńczą (Muszyński 167, Kwiatkowska 70).

W tym kontekście wyróżnia się podręcznik z serii Między nami. W klasie drugiej dotychczasowego gimnazjum uczniowie czytali: Czesława Miłosza Z okna, Edwarda Stachury Ite missa est („Dla wszystkich starczy miejsca / Pod wielkim dachem nieba"), interpretowali plakat Lexa Drewińskiego Rasizm, piosenkę Rogera Watersa Każda świeczka, a w ostatniej klasie - co było regułą we wszystkich książkach do 
kształcenia polonistycznego na tym etapie - teksty poświęcone wielokulturowości i Zagładzie. W zamieszczonym fragmencie Dziecka Noego Schmitta ukrywany przez katolickiego księdza żydowski chłopiec mówi: „Zrozumiałem, że działanie ojca wypływa z solidarności, nie tylko z samej dobroci" (Między nami 61). Ksiądz wykłada mu: „Dla mnie wszyscy ludzie są szlachetnie urodzeni” (Między nami 61). Uczeń poznaje tytuł Sprawiedliwych wśród Narodów Świata, sprowokowana zostaje rozmowa o wyborach i wartościach. Szczególnie tę lekturę, promującą ideę solidarności, warto rozważyć jako propozycję do przeczytania w całości (podstawa programowa pozostawia nauczycielom pewną swobodę wyboru tekstów, a program nauczania także stwarza warunki dla dyskutowania o inności religijnej i rasowej):

[...] ilekroć jakiś naród na ziemi był zagrożony szaleństwem innych ludzi, ojciec Pons postanawiał ocalić przedmioty świadczące o zagrożonej tożsamości. Dość powiedzieć, że w swojej arce Noego zgromadził znaczną liczbę eksponatów: była kolekcja amerykańskich Indian, kolekcja wietnamska, kolekcja tybetańskich mnichów.

Czytając gazety, zwykle mogłem się domyślić, że przy następnej wizycie ojciec Pons oznajmi mi:

- Zakładam kolekcję (Schmitt 128).

Dziś założyłby nie tylko - jak sugeruje zakończenie książki - kolekcję palestyńską, ale także syryjską.

Jakie teksty budujące atmosferę szacunku i empatii obecne są w całości lub we fragmentach $\mathrm{w}$ podręcznikach? W liceum to głównie współczesna polska poezja - przy czym ankietowani uczniowie przywołują tylko Tadeusza Różewicza List do ludożerców i Widziatem Go. Warto zaproponować blok utworów, które polonista mógłby wykorzystać podczas zajęć interpretacyjnych. Są to liczne teksty zarówno wizualne (cykl rzeźb uchodźców Brunona Catalano Voyageurs), jak i poetyckie: Nikt nie jest samotna wyspa Johna Donne'a, Josifa Brodskiego Piosenka o Bośni, Wisławy Szymborskiej Jacyś ludzie, Wietnam czy Psalm (por. Jarosz), Zbigniewa Herberta Pan Cogito o potrzebie ścistości („niewiedza o zaginionych / podważa realność świata”, Herbert 280), poezja Nelly Sachs, Ericha Frieda, Jerzego Ficowskiego, a także wprost odnoszące się do dramatu ludzi podejmujących "podróże rozpaczy” (por. Liberti) wiersze Stanisława Barańczaka Jeżeli porcelana to wyłacznie taka, Czesława Miłosza Po wygnaniu czy Adama Zagajewskiego Spróbuj opiewać okaleczony świat:

[...] Widziałeś uchodźców, którzy szli donikąd,

słyszałeś oprawców, którzy radośnie śpiewali.

Powinieneś opiewać okaleczony świat.

Pamiętaj o chwilach, kiedy byliście razem

w białym pokoju i firanka poruszyła się.

[...] Opiewaj okaleczony świat 
i szare piórko, zgubione przez drozda,

i delikatne światło, które błądzi i znika

i powraca.

(Zagajewski 250)

Warto, by teksty podręcznikowe częściej dotyczyły kondycji ludzi słabych, starszych, zmęczonych, pełnych wewnętrznej pustki i pozwalały kształtować współczującą wyobraźnię (por. wiersz Herberta Pan Cogito czyta gazetę z wersami: „temat do rozmyślania: / arytmetyka współczucia", Herbert 194). Można je adaptować na potrzeby szkoły, objaśniać zagadnienia pokoju i wojny, praw dzieci i - szerzej - praw człowieka. Dom i bezdomność to istotne tematy literatury - polonista znajdzie więc wiele pretekstów, by porozmawiać o sytuacji uchodźców lub tych, którzy żyją na gruzach miast (por. Grzymała-Moszczyńska; Uchodźcy świata: wyzwania humanitarne 1997-1998; Florczak). Polska szkoła nie dość często wykorzystuje także dobre praktyki edukacyjne takich instytucji, jak Nobel Peace Center w Oslo czy UNICEF, organizatorów projektu Syria is my only home, wystawy poświęconej wojnie widzianej oczyma dzieci. Elementem ich tragedii, jeśli przeżyją, będzie wieloletni brak edukacji.

\section{Propozycja lekcji}

Hugon ze św. Wiktora: „Człowiek, który kocha swa ojczyznę, to zaledwie kruchy nowicjusz; ten, dla którego każda ziemia jest jak ojczyzna, to już ktoś silny; ale doskonaty jest ten, dla którego cały świat to obca ziemia".

Edward Said, Orientalizm (Cyt. za: Rotter 48)

Co jeszcze można zrobić, żeby uczynić szkołę potrzebniejszym miejscem, a świat dzięki niej lepszym miejscem do życia? Co mogą zrobić poloniści i polonistki, konkretni ludzie, podczas gdy „jacyś ludzie w ucieczce przed jakimiś ludźmi. / W jakimś kraju pod słońcem / i niektórymi chmurami. // Zostawiają za sobą jakieś swoje wszystko" (Szymborska 353), by dyskurs edukacyjny wyposażyć w treści budzące poszanowanie inności i postawić w centrum problemy ludzi z terenów ogarniętych wojnami oraz uchodźców i uchodźczyń? Michał Bilewicz zauważył, że najskuteczniejszą metodą ograniczającą uprzedzenia,

jest skłanianie do przyjęcia perspektywy członka grupy obcej - próba wyobrażenia sobie jego odczuwania [...]. Dotychczasowe badania dotyczące tego tematu pokazują, że skłonienie badanych do opisania świata (albo choćby typowego dnia) z perspektywy Innego, zdecydowanie silniej wpływa na zmianę postaw niż próba tłumienia czy uświadamiania sobie stereotypów (Bilewicz 74). 
Warto więc podczas zajęć wychowawczych lub polonistycznych przeprowadzić ćwiczenia, w ramach których uczeń zostaje zanurzony w nowy obraz świata, nieznajomą kulturę, obyczaje, w życie toczące się według obcych reguł (por. ćwiczenie dramowe proponowane przez Monikę Koszyńską - uczniowie wcielają się w pasażerów przedziału pociągowego, do którego po długim czasie wsiada nowy podróżny - obcy, zob. Koszyńska).

W 2006 roku ukazała się książka Trudne pytania w dialogu polsko-żydowskim. Jej pomysłodawcy zebrali od polskiej i izraelskiej młodzieży trapiące młodych ludzi pytania związane z Żydami i Polakami (np. Czy to prawda, że wielu Polaków jest antysemitami?, Co Żydzi, którzy wyjechali z Polski, myślą o niej? etc.). Sugeruję, by przywołaną książkę uczynić punktem odniesienia i wykorzystać taką formułę podczas spotkania z uchodźcami, stworzyć listę pytań, poprosić młodzież o zadanie tych najbardziej trapiących: czym jest bezdomność, jak to jest być muzułmaninem w Polsce, jaki stosunek mają religijne islamskie rodziny do dziecka, które porzuca islam, czy uchodźcy rozumieją racjonalne podłoże strachu przed nimi w krajach Europy, związane z zamachami terrorystycznymi? Gdyby uchodźcy zostali zaproszeni do szkół, stworzono by okazję do odpowiedzi na pytania, które mają prawo nasuwać się zespołom uczniowskim. Jeśli okaże się to niemożliwe, warto zaprosić tych, którzy bezinteresownie działają na rzecz budowania wiedzy o rejonach wojen.

Pracując z dziećmi i młodzieżą, trzeba sobie uzmysłowić, iż nikt - ani nauczyciele, ani ich podopieczni, ani rodzice - nie przychodzi na świat ze stereotypami, chęcią izolacji czy segregacji. Tylko edukacja integracyjna i ujmująca człowieka holistycznie pomaga mu pogłębić rozumienie świata i siebie $\mathrm{w}$ nim, z czym musi wiązać się kształcenie wrażliwości językowej. Wspomniana książka Libertiego z 2011 roku, dwa lata później opublikowana w Polsce, pozwala na przeprowadzenie zajęć dotyczących specyfiki reportażu, ale także lekcji uwzględniających rozmowę o języku nienawiści i wrażliwości językowej, wszak dziennikarze posługujący się wyrażeniem „nielegalni imigranci” naruszają etyczne standardy, można mówić o legalnym bądź nielegalnym pobycie człowieka, lecz nie o człowieku samym (ludzi "określano mianem nielegalnych", Liberti 7). Uwzględnienie językowego kształtu przekazów medialnych w refleksji szkolnej wpłynie na kreowanie nowego obrazu świata i nabywanie przez uczennice i uczniów kompetencji merytorycznych, ale jednocześnie społecznych (zdolności empatyczne, prospołeczność) i samorealizacyjnych (Śliwerski 48-49). Po pobiciach obcokrajowców w wielu miastach Polski w latach 2016-2017 warto prześledzić także drabinę uprzedzeń, opracowaną w 1954 roku przez psychologa, Gordona Allporta, na najniższym szczeblu której uwzględniono właśnie zachowania językowe. 


\section{Edukacja na rzecz pokoju}

Marek Ławrynowicz zaznaczał, co odnosi się także do odpowiedzialności nauczyciela:

[...] widzimy tylko to, co zostaje nam pokazane. A to wcale nie musi być najważniejsze. Ludzie, którzy pokazują nam świat, niekoniecznie muszą być bezinteresownie kapryśni [...]. Mogą się kierować banalną chęcią zysku, ideologią, fanatyzmem religijnym, wreszcie zwykłym ludzkim pragnieniem urobienia bliźniego na swój obraz i podobieństwo (Ławrynowicz 24).

Wartościowi nauczyciele i nauczycielki wychowają ludzi dostrzegających - by użyć słów Zbigniewa Herberta - urodę koniunktywu. W podobnym duchu na forum ONZ pierwszy raz po ataku na jej życie przemówiła pakistańska aktywistka Malala Yousafzai:

Podnoszę głos nie po to, by krzyczeć, ale by ludzie bez głosu mogli zostać usłyszani. [...] 9 października 2012 roku talibowie postrzelili mnie w lewą część czoła. [...] Myśleli, że kule nas uciszą. [...] Nie przyjechałam tu, by dokonywać słownej zemsty na talibach czy innych grupach terrorystycznych. Jestem tu, by mówić o prawie do edukacji dla każdego dziecka. O edukacji dla synów i córek ekstremistów, zwłaszcza talibów. Przypomnę mądre powiedzenie: „Pióro jest potężniejsze niż miecz”. Ekstremiści obawiają się książek i piór. Napawa ich lękiem siła edukacji. [...] Książki i długopisy są naszą najpotężniejszą bronią. [...] Jedno dziecko, jeden nauczyciel, jeden długopis i jedna książka mogą zmienić świat (Unicef, przeł. J. R.).

Taka edukacja będzie zapewne miała cechy wyspowej, o której Bogusław Śliwerski w książce Wyspy oporu edukacyjnego tak pisał:

[...] celem wyspowych alternatyw edukacyjnych nie jest uczynienie z nich matrycy, modelu jedynie słusznych i wartościowych rozwiązań, obalenie systemu czy doprowadzenie do anarchii. Ich troską nie jest wzrost ilościowy, lecz jakościowy proponowanych rozwiązań edukacyjnych. O ich zaistnieniu decyduje poziom odmienności, często i radykalności oferowanych przez jej twórców przemian (Śliwerski 33).

Polski system edukacji niedostatecznie daje młodzieży poczucie sprawczości, rozwija autonomiczność uczennic i uczniów oraz wpaja im szacunek dla różnorodności i obcych kultur. Nauczyciele i nauczycielki powinni podejmować tematy związane z pokojem i podczas lekcji przedmiotowych, i wychowawczych (por. How Children Understand War and Peace). Edukacja taka motywuje bowiem do działania na rzecz lepszego świata, jest drogą do budowania pokoju, a więc 
do osiągania wewnętrznej harmonii, nauką miłości i przyjaźni (także z Ziemią), współpracy, braterstwa, moralności, współczucia (por. Learning the Way of Peace 11 oraz Schirch; Hale, Held, Young). Norweski badacz, Johan Galtung, podkreślał, że „pozytywny pokój” wiąże się z troską o warunki dla sprawiedliwego i trwałego pokoju (równym dostępem do pożywienia i czystej wody pitnej, edukacji dla kobiet i dzieci), walką z głodem, chorobami, katastrofami naturalnymi, nierównością, ubóstwem, rasizmem, przemocą instytucjonalną, wyzyskiem, (Galtung 12). W Campaign Statement of the Hague Appeal for Peace Global Campaign for Peace Education z 1999 roku czytamy:

Kultura pokoju zostanie osiągnięta, kiedy obywatele świata zrozumieją globalne problemy, kiedy posiądą umiejętności konstruktywnego rozwiązywania konfliktów, kiedy docenią różnorodność kulturową i zaczną szanować integralność Ziemi. Taka wiedza nie może zostać osiągnięta bez międzynarodowej, zrównoważonej i systematycznej edukacji na rzecz pokoju(Campaign Statement).

To znaczy, że właśnie edukacja na rzecz pokoju (łącząca takie dziedziny wiedzy, jak nauki polityczne, socjologia, historia, antropologia, teologia, psychologia, filozofia) jawi się jako najważniejsze zadanie, stojące przed polską edukacją na wszystkich szczeblach.

\section{BIBLIOGRAFIA}

Arendt, Hannah. „My, uchodźcy”. Przeł. Halina Bortnowska, Pisma żydowskie. Wstępem poprzedził i przekład opracował P. Nowak. Warszawa: Biblioteka Kwartalnika Kronos, 2012.

Attridge, Derek. Jednostkowość literatury. Przeł. Paweł Mościcki. Kraków: Universitas, 2007.

Auden, Wystan Hugh. "Musee des beaux arts”. Przeł. Stanisław Barańczak. Tygodnik Literacki 6 (1991).

Auerbach, Rachela. Pisma z getta warszawskiego. Oprac. Karolina Szymaniak. Warszawa: Żydowski Instytut Historyczny, 2015.

Bartoszewski Władysław, Edelman Marek. I była dzielnica żydowska w Warszawie. Wybór tekstów. Warszawa: Literatura Faktu PWN, 2010.

Bauer, Wolfgang. Przez morze. Z Syryjczykami do Europy. Przeł. Elżbieta Kalinowska. Wołowiec: Czarne, 2016.

Bauman, Zygmunt. Obcy u naszych drzwi. Warszawa: Wydawnictwo Naukowe PWN, 2016.

Ferrante, Elena. Historia zaginionej dziewczynki. Przeł. Lucyna Rodziewicz-Doktór. Katowice: Sonia Draga, 2016.

Bilewicz, Michał. „Jak zmieniać stereotypy i uprzedzenia? Między psychologią a praktyką edukacji do tolerancji". Tolerancyjni. To się dzieje! Red. K. Szotkowska-Beylin, M. Białek-Graczyk. Warszawa: Towarzystwo Inicjatyw Twórczych „ę", 2009.

Bruner, Jerome. Kultura edukacji. Przeł. Tamara Brzostowska-Tereszkiewicz. Kraków: Universitas, 2010. 
Bourdieu, Pierre. Dystynkcja. Społeczna krytyka władzy sązenia. Przeł. Piotr Biłos. Warszawa: wydawnictwo Scholar, 2005.

Chromiec, Elżbieta. Edukacja w kontekście różnicy i różnorodności kulturowej. Kraków: Oficyna Wydawnicza Impuls, 2003.

Donne, John. „Nikt nie jest samotną wyspą”. Hemingway, Ernest, Komu bije dzwon. Przeł. Bogusław Zieliński. Warszawa: Książka i Wiedza, 1987.

Dziuba Zuzanna, Garsztka Tadeusz, Olszowska Gabriela. Do Itaki (III). Kraków: Znak, 2008.

Emre, Yunus. Księga dobrych rad. Przeł. i oprac. Jan Ciopiński. Warszawa: Dialog, 2005.

Florczak, Agnieszka. Uchodźcy w Polsce: między humanitaryzmem a pragmatyzmem, Toruń: Wydawnictwo Adam Marszałek, 2003.

Frankel, Alona. Dziewczynka. Przeł. Leszek Kwiatkowski. Warszawa: Nisza, 2007.

Galtung, Johan. Theories of Peace. A Synthetic Approach to Peace Thinking. Oslo: International Peace Research Institute, 1967.

Gawryluk, Barbara. Teraz tu jest nasz nowy dom. Warszawa: Wydawnictwo Literatura, 2016.

Grzymała-Moszczyńska, Halina. Uchodźcy: podręcznik dla osób pracujących z uchodźcami, Kraków: Zakład Wydawniczy Nomos, 2000.

Hale Thomas, Held David, Young Kevin. Gridlock: Why Global Cooperation is Failing When We Need It Most. Cambridge: Polity, 2013.

Herbert, Zbigniew. Wiersze wybrane. Wybór i oprac. Ryszard Krynicki. Kraków: Wydawnictwo a5, 2007. How Children Understand War and Peace. Ed. Daniel Bar-Tal. San Francisco: Jossey-Bass, 1999.

Inni to także my. Mniejszości narodowe w Polsce: Białorusini, Cyganie, Litwini, Niemcy, Ukraińcy, Żydzi. Red. B. Weigl, B. Maliszkiewicz. Gdańsk: Gdańskie Wydawnictwo Psychologiczne, 1998.

Kluge, Jürgen. „Główne zadanie edukacji”. Kafka. Kwartalnik środkowoeuropejski 7 (2002).

Kołodziejek Iwona, Guzik Agnieszka. Klasa szkolna. Przestrzeń działania nauczyciela polonisty. Kraków: Universitas, 2013.

Koszyńska, Monika. „Lekcja na podstawie tekstu Cyganie a Żydzi - co jest kaszer, a co magerdo?”. Midrasz (3) 2009.

Kwiatkowska, Henryka. Przeżycie literackie a moralne postawy uczniów. Warszawa: Wydawnictwa Szkolne i Pedagogiczne, 1981.

Liberti, Stefano. Na południe od Lampedusy. Podróże rozpaczy. Przeł. Marcin Wyrembelski. Wołowiec: Wydawnictwo Czarne, 2013.

Ławrynowicz, Marek. „Pięć fotografii”. Kafka. Kwartalnik środkowoeuropejski 6 (2002).

Łuczak Agnieszka, Prylińska Ewa. Między nami. Gdańsk: GWO, 2011.

Makówka-Kwapisiewicz, Anna. „Zjawisko antysemityzmu w Polsce na podstawie badań”. Antysemityzm nie jest pogladem. Podręcznik dla edukatorów i edukatorek. Stowarzyszenie Żydowskie Czulent (bez miejsca i daty).

Learning the Way of Peace. A Teacher's Guide to Peace Education. New Delhi: United Nations Educational, Scientific and Cultural Organization, 2001.

Malanowska, Kaja. „Uchodźcy w polskiej szkole”. Edukacja. Przewodnik Krytyki Politycznej. Warszawa: Wydawnictwo Krytyki Politycznej, 2013.

Markowski, Michał Paweł. Życie na miarę literatury. Kraków: Homini, 2011. 
McKee, David. Elmer i hipopotamy. Poznań: Papilon, 2011.

Mikołajewski, Jarosław (a). Wędrówka Nabu. Il. Joanna Rusinek. Kraków, Budapeszt: Austeria, 2016.

Mikołajewski, Jarosław (b). Wielki przypływ. Warszawa: Dowody na istnienie, 2016

Mikołajewski, Jarosław (c). Żebrak. Kraków: Wydawnictwo Literackie, 2016.

Mikulska-Jolles, Agnieszka. „Młodzi Polacy a uchodźcy - co już na ten temat wiemy?”. Hall Dorota, Mikulska Jolles Agnieszka. Analizy, Raporty, Ekspertyzy (1) 2016.

Miłosz, Czesław. „O wygnaniu”. Szukanie ojczyzny, Kraków: Znak, 2001.

Morawska, Iwona. „Dialog kultur jako wyzwanie edukacyjne”. Dialog w edukacji. Red. Barbara Myrdzik, Małgorzata Karwatowska. Lublin: Wydawnictwo UMCS, 2009.

Mościcki, Pawet. Migawki z tradycji uciśnionych. Bydgoszcz-Warszawa: Teatr Polski w Bydgoszczy, Instytut Wydawniczy Książka i Prasa, 2017.

Muszyński, Henryk. Ideat i cele wychowania. Warszawa: Państwowe Zakłady Wydawnictw Szkolnych, 1972.

NieObcy. 21 opowieści, żeby się nie bać. Polscy pisarze dla uchodźców. Warszawa: SPPAH, 2015.

Nikitorowicz, Jerzy. Edukacja regionalna i międzykulturowa. Warszawa: Wydawnictwa Akademickie i Profesjonalne, 2009.

Nowak, Ewa. Kot, który zgubił dom. Warszawa: Egmont Polska, 2016.

Piątkowska, Renata. Która to Malala. Warszawa: Wydawnictwo Literatura, 2016.

Piskorski, Jan M. Wygnańcy. Warszawa: Państwowy Instytut Wydawniczy, 2010.

Rotter, Andrew J. Bomba atomowa. Świat wobec zagrożenia. Przeł. Jacek Dobrowolski. Warszawa: Wydawnictwo Naukowe PWN, 2011.

Rozmawiajmy o uchodźcach. Globalnie - lokalnie o migracjach. Warszawa: Centrum Edukacji Obywatelskiej, 2016.

Rozmawiajmy o uchodźcach. Migracje i wielokulturowość. Warszawa: Centrum Edukacji Obywatelskiej, 2016.

Sanna, Francesca. Podróż. Przeł. Agata Napiórska. Il. Francesca Sanna. Kultura Gniewu (bez miejsca wydania), 2016.

Schirch, Lisa. Conflict Assessment and Peacebuilding Planning. Sterling: Kumarian Press, 2013.

Schmitt, Eric-Emmanuel. Dziecko Noego. Przeł. Barbara Grzegorzewska. Kraków: Wydawnictwo Znak, 2007.

Szejnert, Małgorzata. Wyspa klucz. Kraków: Znak, 2009.

Szkoła równości. Temat lekcji: Wszyscy o wszystkim mało wiemy. Scenariusze z reportażami. Warszawa: Towarzystwo Edukacji Antydyskryminacyjnej, 2016.

Szymborska, Wisława. „Jacyś ludzie”. Wiersze wybrane, Kraków: Wydawnictwo a5, 2010.

Śliwerski, Bogusław. Wyspy oporu edukacyjnego. Kraków: Oficyna Wydawnicza „Impuls”, 1993.

Tan, Shaun. Przybysz. Kultura Gniewu (bez daty wydania), 2009.

Teksty Drugie 3 (2016). Temat numeru: literatura migracyjna.

Uchodźcy świata: wyzwania humanitarne 1997-1998. Warszawa: UNHCR, Wydawnictwo Naukowe PWN, 1998.

Uchodźcy w Polsce i Europie: stan prawny i rzeczywistość. Red. T. Gardocka, J. Sobczak. Toruń: Wydawnictwo Adam Marszałek, 2010. 
Witek, Rafał. Chtopiec z Lampedusy. Warszawa: Wydawnictwo Literatura, 2016.

Zagajewski, Adam. „Spróbuj opiewać okaleczony świat”. Wiersze wybrane. Kraków: Wydawnictwo a 5, 2010.

\section{Źródła internetowe:}

Campaign Statement of the Hague Appeal for Peace Global Campaign for Peace Education, <http://www. haguepeace.org/index.php?action=pe>

Adichie, Chimamanda, Niebezpieczeństwo jednej historii, przeł. Aneta Cruz-Kąciak, <https://www.ted. com/talks/chimamanda_adichie_the_danger_of_a_single_story?language=pl>. Web. 29.07.2017

Jarosz, Jadwiga, Granice państw - irytujace ograniczenie czy uspokajający porządek? "Psalm" Wistawy Szymborskiej <http://www.ceo.org.pl/sites/default/files/news-files/scenariusz_granice_panstw_irytujace_ograniczenie_czy_uspokajajacy_porzadek_psalm_wislawy_szymborskiej_autorka_jadwiga_jarosz_0.pdf >. Web.31.12.2016.

Kristof, Nicholas. <http://mobile.nytimes.com/2016/08/25/opinion/anne-frank-today-is-a-syriangirl.html?_r=2\&referer=https\%3A\%2F\%2Fwww.google.com.tr\%2F.>. Web.31.12.2016.

Unicef - < https://www.unicef.ie/stories/one-child-one-teacher-one-book-and-one-pen-can-change-the-world/> Web. 9.09.2017

<http:/ / kulturaliberalna.pl/2015/09/29/apel-autorow-ksiazek-dla-dzieci-ws-uchodzcow /

Kodeks Etyki Nauczycielskiej. <http://admzsg.edu.pl/zzyciaszkoly/wp-content/uploads/2007/06/ kodeks-etyki-nauczycielskiej.pdf>. Web. 29.07.2017

<http:/ / brunocatalano.com/sculpture-bronze/sculpture-en-bronze-bruno-catalano.php?galerie=1>. Web. 29.07.2017

https://www.nobelpeacecenter.org/en/exhibitions/syria-is-my-only-home/. Web.31.12.2016>

< https://amnesty.org.pl/4minuty/> Web. 29.07.2017

\section{Film}

Ostatni z Aleppo. Reż: Firas Fayyad, Larm Fim, Aleppo Media Center, 2017. 